\title{
KEEFEKTIVITASAN VIDEOTRON \\ DALAM MENYAMPAIKAN PESAN IKLAN KEPADA MASYARAKAT
}

Oleh : Andry Priyadharmadi Purnama dan Akbar Abu Thalib

Dosen Prodi Ilmu Komunikasi

Fakultas Ekonomi dan Ilmu-ilmu Sosial

Universitas Fajar

Email : andrypurnamaunifa@gmail.com

\section{Abstract}

In technology era nowadays, almost all promotion and information media from the company as well as the government switch to print media from visual media. This is because people today prefer to use applied technology for communication and technology. This research aims to review Videotron effectivity on conveying the commercial message to the society. This research was conducted by qualitative description with the primary data sources and secondary. Data was collected by direct observation in Videotron location and interviewed some speaker and Videotron manager in Makassar. Result of this research shows Videotron quite effective to convey a commercial message by giving good visualization. Videotron also become an effective media to present several advertisements on one media therefore can reduce visual trash. In addition, near from traffic light can increase enticement of Videotron that can be a significant strategy to publish the information and attract readers attention. Videotron media has positive impact to the government because of giving a role to to give information about their program and additional aesthetic for the hometown. Implication of this Videotron according society can disturb driver concentration, give strong light and can be hacked by someone.

Key words : effectivity, message, commercial, videotron, implication

\section{Pendahuluan}

Saat ini perkembangan dunia pemasaran di era globalisasi telah berkembang pesat, terutama dalam bidang marketing communication, yang sangat dikenal dengan komunikasi pemasaran. Pemasar tidak lagi mengandalkan satu media saja sebagai alat komunikasi pemasarannya, melainkan memadupadankan dengan beberapa media lainya. Hal ini yang menjadi salah satu penyebab, para pemasar beramai-ramai menggunakan berbagai media dan saluran sebagai alat penyampai pesan, bahkan pemasar tidak lagi menggunakan media konvensional atau media pada umumnya sebagai strategi pemasarannya (Kotler, 2014:5). Menemukan media yang baru, kreatif dan berinovasi dalam dunia pemasaran menjadi kunci untuk mecapai suatu tujuan dari komunikasi pemasaran itu sendiri.

Menurut Kotler, terdapat 5 alat pemasaran, yaitu pemasaran langsung, promosi penjualan, hubungan masyarakat, penjualan personal, dan periklanan. Periklanan adalah salah satu dari lima teknik yang digunakan untuk mempersuasif para konsumen secara tidak langsung. Secara sederhana iklan didefenisikan suatu pesan yang menawarkan suatu produk barang atau jasa yang 
ditujukan kepada masyarakat secara luas menggunakan suatu media massa tertentu, dengan menggunakan pesan yang bersifat persuasif untuk membujuk para konsumen. Iklan dan promosi dalam media massa sudah menjadi bagian yang tak terpisahkan dari sistem ekonomi dan sosial masyarakat modern. Dewasa ini, iklan sudah sangat berkembang menjadi sistem komunikasi yang sangat penting, tidak hanya bagi pemasar barang atau jasa, namun juga bagi konsumen.

Menurut Cangara, (2006), media massa adalah alat yang digunakan dalam menyampaikan pesan - pesan dari sumber kepada khalayak (penerima) dengan menggunakan alat - alat komunikasi mekanis seperti surat kabar, film, radio maupun televisi. Pengaruh media massa berbeda-beda terhadap setiap individu. Hal ini disebabkan karena adanya perbedaan pola pikir, perbedaan sifat yang berdampak pada pengambilan sikap, hubungan sosial sehari-hari, dan perbedaan budaya. Media massa merupakan salah satu bentuk kemajuan teknologi dalam bidang informasi dan komunikasi.

Media massa memiliki beberapa macam jenis di antaranya media cetak, media elektronik, new media atau media online dan juga media luar ruangan sebagai media promosi. Media promosi adalah sarana yang digunakan untuk mengkomunikasikan suatu produk/jasa/image/perusahaan ataupun yang lain untuk dapat dikenal oleh masyarakat secara luas. Di mana dengan penyampaian pesan ini diharapkan konsumen bisa mengetahui, mengakui, memiliki, dan mengikatkan diri pada suatu barang/jasa/produk/image/perusahaan yang menjadi target sasarannya. Salah satu media promosi yang cukup digemari saat ini dalam menyampaikan pesan iklan kepada khalayak dalam bentuk video yang disebut videotron. Videotron merupakan media baru yang menayangkan iklan menggunakan video light - emiting diodes (LED). Led adalah tipe pencahayaan hemat energy karena menggunakan semikonduktor untuk mengubah listrik menjadi cahaya. Videotron ini sangat sering kita jumpai di pusat-pusat kota dan di perempatan jalan yang terdapat lampu merah.

Namun selain itu videotron juga dapat digunakan di dalam ruangan pada acara-acara mini konser sebagai media live view. Videotron bisa disebut sebagai reklame digital karena menghasilkan visual gambar yang bergerak layaknya video. Kelebihan menggunakan media promosi periklanan jenis videotron adalah kemampuan dalam menampilkan gambar visual bergerak secara detil dengan resolusi tinggi sehingga membuat tampilan iklan lebih menarik dan lebih profesional. Hampir disetiap sudut kota-kota besar di Indonesia sudah menggunakan media promosi seperti videotron sebagai media penyampai pesan iklan kepada khalayak, seperti kota Jakarta, Jogjakarta, Balikpapan, Denpasar, Bandung dan juga kota Makassar.

Beberapa bulan terakhir ini di kota Makassar sangat banyak terpasang media videotron sebagai alat promosi periklanan untuk menyampaikan suatu pesan kepada masyarakat secara luas. Media ini sangat membantu untuk menyampaikan suatu pesan terkhusus dalam bidang komersil namun tidak menutup kemungkinan bagi instansi pemerintah untuk menggunakan media luar ruang ini untuk mengkampanyekan suatu program milik pemerintah. Seperti menyampaikan informasi mengenai kesehatan, ekonomi, sosial, keagamaan hingga pariwisata. Ada beberapa media luar ruang videotron yang terdapat di kota Makassar, seperti di jalan A.P.Pettarani, Hotel Clarion Makassar, Kantor Suzuki Galesong, kantor Abu Tours.com dan lain-lain. 
Adapun alasan peneliti memilih videotron di jl. A.P Pettarani dikarenakan letaknya yang sangat strategis yaitu berada di sekitar kantor pemerintahan, kantor swasta dan pusat perbelanjaan, tempat kuliner serta hotel-hotel di kota Makassar. Di samping itu, berbagai keluhan para pengguna jalan raya terhadap cahaya yang ditampilkan oleh videotron juga menjadi salah satu tujuan peneliti ingin meneliti efektivitas informasi dan implikasi yang ditampilkan oleh videotron.

Media videotron yang terletak di jalan A.P Pettarani, Kota Makassar sangat membantu para pelaku iklan, karena sangat mudah dilihat dan dibaca pengguna jalan raya khususnya para masyarakat Kota Makassar. Selain itu videotron juga dapat menampilkan berbagai informasi tentang Makassar dari berbagai sektor, seperti sektor pariwisata, kesehatan, ekonomi, sosial dan budaya sehingga dengan kehadiran media luar ruangan seperti ini dapat membantu pemerintah dalam mempromosikan keunggulan-keunggulan yang dimiliki oleh Provinsi Sulawesi Selatan. Maka dari itu peneliti termotivasi untuk mengukur seberapa efektif pesan iklan yang disampaikan videotron yang terletak di jalan A.P Pettarani, Kota Makassar kepada para pengguna jalan raya yang sudah sering melihat informasi pada media luar ruangan tersebut.

Berdasarkan gambaran tersebut, maka dapat dirumuskan dua rumusan masalah sebagai berikut:

1. Untuk mengetahui sejauhmana keefektivitasan videotron dalam menyampaikan informasi pesan kepada masyarakat pengguna jalan raya.

2. Mengetahui implikasi negative yang di timbulkan videotron dalam menyampaikan informasi pesan kepada masyarakat pengguna jalan raya.

\section{TINJAUAN PUSTAKA}

\section{Teori Uses and Gratification}

Uses and Gratification Theory adalah Teori Penggunaan dan Pemenuhan Kebutuhan. Theory Uses and Gratification adalah salah satu teori komunikasi massa di mana titik berat penelitian dilakukan pada pemirsa atau khalayak sebagai penentu pemilihan pesan dan media. Uses and Gratification Theory yang merupakan salah satu dari teori komunikasi massa melihat audiens dari proses komunikasi massa sebagai individu yang aktif, selektif dan memiliki tujuan tertentu terkait dengan terpaan media kepadanya. Uses and Gratification meneliti asal mula kebutuhan manusia secara psikologis dan sosial, yang menimbulkan harapan tertentu dari media massa atau sumber-sumber lain dan menimbulkan pemenuhan kebutuhan penelitian yang menggunakan Uses and Gratification model memusatkan perhatian pada kegunaan isi media untuk memperoleh gratifikasi atau pemenuhan kebutuhan.

Uses and Gratification (penggunaan dan Pemenuhan kepuasan) merupakan pengembangan dari teori atau model jarum hipordemik (jarum suntik). Model ini tidak tertarik pada apa yang dilakukan oleh media pada diri seseorang, tetapi ia tertarik dengan apa yang dilakukan orang terhadap media. Khalayak dianggap secara aktif menggunakan media untuk memenuhi kebutuhannya. 
Menurut Herbert Blumer dan Elihu Katz (1974) dalam Effendy (2003:24), mengatakan bahwa penggunaan media memainkan peran aktif untuk memilih dan menggunakan media tersebut. Dengan kata lain penggunaan media tersebut adalah pihak yang aktif dalam proses komunikasi. Artinya teori uses and gratification mengasumsikan bahwa pengguna mempunyai pilihan untuk memuaskan kebutuhannya.

Uses and Gratification menunjukkan bahwa yang menjadi permasalahan utama bukanlah bagaimana media mengubah sikap dan perilaku khalayak, tetapi bagaimana media memenuhi kebutuhan pribadi dan sosial khalayak. Khalayak dianggap secara aktif dengan sengaja menggunakan media untuk memenuhi kebutuhan dan mempunyai tujuan. Studi dalam bidang memusatkan perhatian pada penggunaan (uses) isi media untuk mendapat kepuasan (Gratification) atas pemenuhan kebutuhan seseorang dan dari situlah timbul istilah Uses Gratification. Sebagian besar prilaku khalayak akan dijelaskan melalui berbagai kebutuhan dan kepentingan individu. Dengan demikian, kebutuhan individu merupakan titik awal kemunculan teori ini.

\section{Pengertian Iklan}

Iklan merupakan salah satu bentuk dari komunikasi pemasaran, bersama-sama dengan komponen lainnya seperti personal selling, promosi, penjualan, dan publisitas semuanya merupakan komponen promosi dalam marketing mix. Kasali (1992:10) mengemukakan kata iklan (advertising) berasal dari bahasa Yunani yang artinya "mengubah jalan konsumen untuk membeli”.

Iklan adalah segala bentuk presentasi non-pribadi dan promosi gagasan barang atau jasa oleh sponsor tertentu yang harus dibayar (Kotler, 2005:277) dengan kata lain Iklan televisi adalah sebuah dunia magis yang dapat mengubah komoditas kedalam kegemerlapan yang memikat dan mempesona menjadi sebuah sistem yang keluar dari imajinasi dan muncul kedalam dunia nyata melalui media Sebagai salah satu bagian dari komunikasi pemasaran, Iklan juga merupakan suatu bentuk komunikasi massa yang dibiayai oleh sponsor, dalam hal ini perusahaan produsen barang dan jasa yang di dalamnya menyediakan informasi mengenai produk atau jasa yang dihasilkan, bersifat persuasif sehingga membangkitkan minat beli dari target audience. Hal ini sesuai dengan apa yang dikatakan Kriyantono (2008 : 174) pengertian iklan adalah sebagai bentuk komunikasi nonpersonal yang menjual pesan-pesan persuasif dari sponsor yang jelas untuk mempengaruhi orang membeli produk dengan membayar sejumlah biaya untuk media.

Menurut Rotzoill (1986) secara mendasar berpendapat bahwa iklan mempunyai empat fungsi utama (Widyatama, 2005:147). Empat fungsi utama tersebut yaitu:

\section{a. Fungsi Precipitation}

Fungsi mempercepat berubahnya suatu kondisi dari keadaan yang semula tidak bisa mengambil keputusan terhadap produk menjadi dapat mengambil keputusan. Fungsi ini misalnya meningkatkan permintaan atas suatu produk dan menciptakan kesadaran dan pengetahuan tentang suatu produk. 


\section{b. Fungsi Perssuasion}

Membangkitkan keinginan dari khalayak sesuai pesan yang diiklankan. Hal ini meliputi persuasi atas daya tarik emosi, menyebarkan informasi tentang ciri-ciri suatu produk dan membujuk konsumen untuk tetap membeli.

\section{c. Fungsi Reinforcement}

Fungsi ini berarti iklan mampu meneguhkan keputusan yang telah diambil oleh khalayak. Peneguhan ini meliputi mengabsahkan daya beli para konsumen yang sudah ada terhadap suatu produk dan mengabsahkan keputusan sebelumnya dalam mengkonsumsi produk.

\section{d. Fungsi Reminder}

Fungsi iklan yang mampu mengingatkan dan semakin meneguhkan terhadap produk yang diiklankan, misalnya memperkuat loyalitas konsumen akan produk yang sudah disenanginya.

\section{Media Baru}

Media baru (new media) merupakan simplifikasi terhadap bentuk media di luar 5 media massa besar konvensional, seperti televisi, radio, majalah, koran, dan film. Diperkenalkan mulai tahun 1990-an, istilah media baru (new media) pada awalnya mengandung arti negletik (penolakan), media baru bukanlah media massa. Sifat media baru adalah cair (fluids), kolektivitas individual, dan menjadi sarana untuk membagi peran kontrol dan kebebasan.

Martin Lister dan Jon Dovey menjelaskan definisi media baru melingkupi:

a. New textial experience. Jenis-jenis baru genre dan format teks, hiburan, pola, dan kenikmatan dalam mengonsumsi media.

b. New way of representating the world. Media yang tak mudah didefinisikan, tetapi mampu memberi pengalaman dan kemungkinan yang representatif.

c. New relationship between subjects (user and consumer) and media technologies. Perubahan dalam menggunakan dan meresapi citra dan media komunikasi dalam kehidupan sehari-hari yang terinvestasikan dalam teknologi media.

d. New experience of the relationship between embodiment, identity, and community. Pergeseran dalam pengalaman pribadi dan sosial mengenai waktu, ruang, dan tempat (baik lokal maupun global) mempengaruhi pengalaman kita di dunia.

Menurut Jenkins (2002:2), membagi konvergensi dalam empat jenis, yaitu konvergensi teknologi, konvergensi ekonomi, konvergensi sosial (organik), serta konvergensi budaya dan global.

a. Konvergensi teknologi merupakan proses penggabungan secara digital berbagai bentuk isi media. Jika teks, image (citra), dan suara telah diubah menjadi bentuk byte, maka dapat mengkompilasi menjadi satu dan mengirimkannya ke berbagai platform. 
b. Konvergensi ekonomi berhubungan dengan integrasi industri hiburan. Konvergensi ekonomi merupakan bentuk baru konglomerasi media, dimana satu perusahaan dapat bergerak dibadang film, televisi, buku, news online provider, dan lain sebagainya.

c. Konvergensi sosial adalah perilaku dan strategi dari konsumen atau khalayak yang dapat menjalankan aktivitas atau menyelesaikan beberapa pekerjaan sekaligus.

d. Konvergensi budaya merupakan persilangan dari berbagai teknologi media, industri, dan konsumen. Konvergensi media telah mendorong partisipasi dan perkembangan budaya popular, menghubungkan antara konsumen dengan industri media serta memunculkan berbagai bentuk informasi berbiaya rendah. Konvergensi budaya juga mendorong terjadinya penggunaan multimedia dalam produksi kreatif dan jurnalistik.

Media baru (new media) merujuk pada perkembangan teknologi digital, tetapi media baru sendiri tidak serta merta berarti media digital. Video, teks, gambar, grafik yang diubah menjadi data-data digital berbentuk byte, hanya merujuk pada sisi teknologi multimedia, salah satu dari tiga unsur dalam media baru, selain ciri interaktif, dan intertekstual. Berbicara mengenai media baru, maka tak dapat dipisahkan dengan keberadaan internet. Internet merupakan jaringan antar komputer, "put simply internet is an almost global network connecting millions of computers. Using a number of egreed format (knows as protocol), users are able to transfer data (or file), from one computer to the next" (Thurlow, 2009:28) Namun secara cultural, Thurlow dkk (2009) menjelaskan internet sebagai transformasi kultural dan sosial yang dibawa oleh komputer dan internet. Lebih dari itu, aspek ini berfokus pada interaksi sosial seperti bagaimana identitas, hubungan komunitas, dipengaruhi atau berubah karena internet.

Pada dasarnya media, baik media baru atau media konvensional telah berperan dalam perubahasan sosial masyarakat, bahkan hingga perubahan budaya. Perbedaan signifikan dari media lama dan baru terletak pada kesempatan pengguna untuk berinteraksi. Interaktivitas adalah kemampuan dari sistem komunikasi baru untuk menjawab pengguna lain, hampir seperti partisipasi individu dalam suatu percakapan. Media massa baik surat kabar, radio, televisi, dan radion relatif memiliki tingkat interaktivitas yang berbeda dibandingkan dengan media baru.

Pavlik (1996:2) menjelaskan bahwa akibat dari digitalisasi teknologi yang merupakan bentukan dari media baru sangat nyata dalam merubah berbagai bentuk komunikasi manusia. Pavlik menjelaskan secara teknis media baru memiliki fungsi dalam teknis, distribusi, display, dan penyimpanan. Hal yang menarik adalah dalam media baru proses ini berlangsung cepat dan terus berputar, sebab media baru memberi kemungkinan interkasi untuk berlangsung terus menerus.

\section{Media Iklan Luar Ruang}

Iklan luar ruang mulai menjadi incaran para pelaku periklanan, baik pengiklan itu sendiri ataupun agensi periklanan. Iklan luar ruang memiliki medium yang fleksibel juga jangkauannya yang spesifik menjadikan media luar ruang ini menjanjikan bagi pengiklan. Menurut Tjiptono dalam bukunya Strategi Bisnis Pemasaran: "Media luar ruangan adalah media yang berukuran besar dipasang ditempat-tempat terbuka seperti dipinggir jalan, dipusat keramaian atau tempat- 
tempat khusus lainnya, seperti di dalam bus kota, gedung, pagar tembok dan sebagainya" (Tjiptono, 2008: 243).

Jangkauannya yang luas dan lokal sangat menjanjikan bagi beberapa produk tertentu, seperti untuk publikasi brand activation, produk kecantikan, dan sebagainya. Pada dasarnya, apapun bentuk iklan media luar, baik cetak maupun elektronik, adalah sama. Keduanya memiliki jangkauan yang sama, frekuensi yang sama. Perbedaannya terletak pada cara menikmati iklan tersebut, iklan cetak membutuhkan audiens yang lebih aktif untuk membaca semua informasi yang diiklankan, sedangkan iklan elektronik membutuhkan waktu untuk mencerna. Keduanya memiliki kelebihan dan kekurangannya masing-masing yang menjadikan kedua media iklan ini sama kuatnya untuk menjadi pertimbangan para pengiklan.

Menurut peraturan perundang-undangan mengenai reklame, iklan luar ruang dan reklame diklasifikasikan sebagai berikut:

1. Reklame papan/Billboard adalah reklame yang berbentuk bidang, dengan bahan terbuat dari kayu, logam, kaca, plastik dan bahan lain yang sejenis sesuai dengan perkembangan jaman, yang pemasangannya berdiri sendiri, menempel pada bangunan dengan konstruksi tetap dan reklame tersebut bersifat permanen.

2. Reklame megatron/videotron adalah reklame yang berbentuk bidang dengan komponen elektronik berbentuk LED pixel yang pemasangannya berdiri sendiri, menempel bangunan atau diatas bangunan dengan konstruksi tetap atau permanen.

3. Reklame baliho adalah reklame yang berbentuk bidang dengan bahan terbuat dari kayu, logam, plastik dan bahan lain yang sejenis sesuai perkembangan jaman, yang pemasangannya berdiri sendiri dengan konstruksi sementara dan bersifat semi permanen.

4. Reklame kain adalah reklame yang berbentuk spanduk, umbul-umbul, banner, dengan bahan kain, plastik, dan yang sejenis yang pemasangannya berdiri sendiri, menempel bangunan, atau diatas bangunan dengan konstruksi sementara dan bersifat semi permanen.

5. Reklame melekat (stiker) adalah reklame yang berbentuk bidang dengan bahan kertas, plastik, logam yang pemasangannya dengan cara ditempelkan dan bersifat semi permanen.

Adapun aspek estetika dapat dilihat berdasarkan ukuran iklan luar ruang, jarak antara iklan luar ruang, lokasi penempatan iklan luar ruang serta tingkat kepadatan iklan luar ruang.

1. Aspek-aspek tersebut jika dilaksanakan dengan baik maka dapat memberikan dampak indah, menarik, dan mempesonakan di dalam penempatan iklan luar ruang.

2. Ukuran Luar: Ruang Ukuran iklan luar ruang yang dimaksud dalam penelitian ini adalah besarnya iklan luar ruang yang diukur dari panjang dan tinggi suatu iklan luar ruang.

3. Jarak antara iklan luar ruang: Jarak antara iklan luar ruang ini dilihat dari jarak penempatan antara iklan yang satu dengan lainnya 
4. Lokasi penempatan iklan luar ruang: Iklan luar ruang harus memperhatikan dengan kondisi sekitar, iklan luar ruang yang baik harus memperhatikan kenyamanan pengguna jalan maupun keseimbangan lingkungan yang itu semua dapat memberikan keindahan bagi kota.

5. Tingkat kepadatan iklan luar ruang: Tingkat kepadatan iklan luar ruang ini berhubungan dengan banyaknya iklan luar ruang pada suatu titik tertentu.

\section{Videotron}

Setelah kedatangan teknologi digital, Billboard yang dicat dengan tangan diganti dengan teknologi komputer. Selanjutnya periklanan outdoor pun berkembang. Iklan yang menempel pada Billboard sekarang ini lebih banyak dibuat menggunakan teknologi komputer atau teknologi digital. Bahan yang digunakan untuk mencetak iklan dengan teknologi digital ini bisaanya tahan air dan juga panas yang disebut vinil (Suyanto, 2006:2-3). Papan reklame elektronik merupakan display yang terbuat dari led multi warna (full color) dan dapat menampilkan gambar bergerak (video). Papan reklame ini dapat menggantikan fungsi televisi terutama untuk media luar ruang (www.netraled.com).

Videotron sering juga disebut sebagai digital Billboard atau Billboard elektronik. Videotron sendiri sejenis dengan billboard, hanya berbeda formatnya saja. Videotron menggunakan format audio video. Videotron merupakan sebuah televisi besar berukuran 2 X 4 meter. Layar videotron terbuat dari sekian banyak susunan lampu-lampu LED atau dalam bahasa Inggrisnya Light Emitting Diode dan memiliki warna yang sangat banyak sehingga gambar yang dihasilkan seperti gambar yang sering kita lihat di televisi (singgihadvert.blogspot.com).

Billboard elektronik (videotron) merupakan media luar ruang yang berbentuk display atau digital yang berfungsi untuk melengkapi kekurangan papan reklame. Billboard elektronik dapat menayangkan banyak iklan sekaligus sehingga tidak memakan tempat. Disamping itu, materi iklan dapat diganti dalam waktu singkat, tampilan iklan lebih meriah, bergerak dan tidak monoton. Dengan menggunakan Billboard elektronik tayangan iklan menjadi lebih fleksibel dan dapat disesuaikan dengan kondisi dilapangan. Dengan adanya media luar ruangan ini perusahaan dapat mempromosikan produknya lebih luas tanpa dibatasi waktu dengan sasaran jangkauan yang lebih luas serta mengenai banyak kalangan.

Billboard elektronik merupakan media iklan yang relatif baru di Indonesia, mulai masuk tahun 2006 dan diadobsi dari Amerika yang telah menggunakannya sejak tahun 90-an. Ukuran billbord berbeda-beda, tetapi pada dasarnya prinsip kerja sign dan Billboard elektronik relatif sama karena menggunakan slide statis yang menggunakan serial animasi atau video. Media ini mengaplikasikan teknologi yang yang memiliki visual impact tinggi dengan biaya relatif murah dan hemat listrik serta pengiklan dapat mengontrol tampilan iklan dan menyesuaikan khalayak yang diinginkan. Kemampuan menampilkan gambar gerak dan audio, animasi, memungkinkan adanya cerita yang menarik. Teknologi ini juga memungkinkan penyesuian secara otomatis terhadap semua kondisi pencahayaan sehingga akan tetap terlihat dalam semua cuaca baik pagi, siang atau malam (mirzubolgfree.blogspot.com). 
Dahulu perusahaan menggunakan media konvensional dalam beriklaan. Pada penggunaan iklan konvensional biasanya membutuhkan tempat, terkesan tidak teratur dan semrawut hal ini bisa dilihat dari papan reklame yang menawarkan banyak produk dengan ukuran yang tidak sama antara satu dengan yang lainya sehingga terkesan kumuh dan tidak menyenangkan. Saat ini teknologi digital berkembang cepat sehingga mempengaruhi cara komunikasi dan promosi. Salah satu media iklan yang menggunakan teknologi digital adalah videotron atau Billboard elektronik. Billboard elektronik atau large electronic display (LED) atau light emitting diodes (LED) video display atau digital Billboard sering disebut videotron bisa menjadi solusi untuk mengatasi kekurangan papan reklame. Videotron dapat menayangkan banyak iklan sekaligus sehingga tidak memakan tempat.

Dengan videotron materi iklan bisa diganti dalam waktu singkat dan tampilan iklan yang lebih meriah, bergerak dan tidak monoton. Pengoperasiannya dengan sistem komputerisasi mampu membuat tayangan iklan menjadi fleksibel, sesuai dengan kondisi dilapangan. Kekurangannya pada awal pembuatannya membutuhkan biaya sangat besar.

\section{METODE PENELITIAN}

Penelitian ini menggunakan metode deskriptif dengan pendekatan kualitatif. Metode deskriptif bertujuan untuk mengeksplorasi penelitian lebih mendalam. Dalam operasional penelitian, peneliti melakukan wawancara, pengamatan ditambah dengan studi pustaka, kemudian berusaha memahami dan menganalisisnya. Lokasi penelitian menurut Arikunto (2005:88) tempat dimana penelitian dilakukan. Langkah-langkah di lapangan dilakukan secara sistematik sebagai usaha untuk menjawab sejumlah pertanyaan yang telah peneliti siapkan.

Untuk melengkapi data dalam upaya memperoleh data yang akurat tentang penelitian, dilakukan wawancara dengan sumber data yaitu pemilik videotron dalam hal ini diwakili oleh pak Gianto di kantor Media AD jalan Sulawesi Kota Makassar. Wawancara dilakukan mendalam dengan pola tanya jawab yang dikemas dalam sebuah percakapan yang telah ditentukan sebelumnya oleh peneliti.

Untuk menentukan jumlah ideal informan ditentukan pada saat peneliti berada di lapangan dengan menggunakan teknik purposif. Penulis menentapkan 30 informan pengguna jalan atau yang berada dekat dengan lokasi videotron. Hal ini diperlukan guna memperoleh deskripsi serta melacak informasi yang ada informasn secara lengkap.

Untuk kepentingan analisis, sesuai dengan tema pokok penelitian ini, maka penelaahan bahan-bahan literer merupakan bagian dari proses pencarian data itu sendiri pengumpulan dokumen merupakan cara lain yang diterapkan dalam mengumpulkan data penelitian yang bertujuan untuk menggali dan memperdalam informasi tentang efektivitas dan ketersampaian pesan iklan pada media videotron.

Pada tahap pengumpulan data, yang digunakan dalam mengumpulkan data primer dan data sekunder. Penelitian ini menggunakan metode penelitian deskriptif dengan pendekatan kualitatif, maka teknik pengumpulan data penelitian digunakan metode wawancara kepada pemilik videotron dan 30 informan, kemudian studi pustaka dan pengamatan langsung. 
Proses penelitian dilakukan secara bertahap, pada langkah awal dimulai dengan pengumpulan data. Kemudian hasil dari pengumpulan tersebut direduksi. Kegiatan reduksi ini melingkupi merangkum, memilih informasi yang sifatnya penting dari beberapa jumlah data yang telah diperoleh di lapangan. Penelitian ini menggunakan Teknik pengumpulan data melalui pengamatan dan wawancara mendalam.

Dalam proses analisis data, menurut Miles dan Huberman (1984:21) menyatakan ada tiga macam kegiatan dalam analisis kualitatif yaitu reduksi data, sajian data dan penarikan simpulan dan verifikasi data. penelitian ini dimulai pertama-tama dengan menelaah seluruh data yang tersedia dari berbagai sumber, yaitu wawancara dan pengamatan hasil pengamatan di lapangan dan sebagainya. Dalam proses ini juga dilakukan pemeriksaan data guna memastikan kelengkapan informasi dan data sesuai dengan kebutuhan penelitian. Selanjutnya pada tahap akhir peneliti melakukan penarikan simpulan dari data-data yang telah direduksi.

\section{HASIL PENELITIAN DAN PEMBAHASAN}

Sumber penelitian menjelaskan pengiklan atau pihak-pihak yang menggunakan media videotron terdiri dari berbagai kalangan baik dari perusahaan swasta, perusahaan BUMN hingga pemerintah daerah. Media ini marak digunakan sebagai media informasi, terlepas dari sifatnya komersil ataupun dalam hal layanan masyarakat. Untuk bentuk iklan komersil menampilkan suatu produk maupun jasa yang disebarluaskan demi ketercapaian tujuan informasi suatu perusahaan, baik untukperusahaan swasta maupun BUMN, sedangkan iklan layanan masyarakat ialah iklan bukan komersil dengan tujuan mempersuasi pengguna jalan untuk mematuhi dan melaksanakan himbaun tersebut. Adapun contoh iklan layanan masyarakat diantaranya larangan penggunaan handphone saat mengemudi, iklan layanan masyarakat pemilu dan iklan layanan masyarakat peduli pajak.

Terkait mengenai durasi iklan dan waktu - waktu efektif pada media videotron. Pemilik videotron dalam hal ini diwakili pak Gianto mengatakan bahwa semua waktu kerja videotron mulai dari pukul 06-00 pagi hingga 24.00 malam adalah waktu efektif, karena tidak ada lagi waktu, dimana keadaan jalan kosong dan tidak ada pengendara yang lalu lalang melintasi jalan terebut. Namun jika mengacu pada tingkat kepadatan jumlah kendaraan di jalan raya yaitu berkisar pukul 07-00 hingga 09.00 pagi. Dimana pada saat tersebut pengendara jalan bersamasama untuk menuju tempat aktivitasnya masing-masing sehingga volume kendaraan yang melintas pada saat itu meningkat hingga dua kali lipat. Selain di pagi hari, hal ini juga terjadi pada waktu sore hari berkisar pukul 04-06 sore, dimana saat pengendara ingin kembali ke rumah masing-masing setalah beraktivitas.

Untuk tahap-tahap penayangan iklan pada media videotron pak Gianto menjelaskan cukup mudah dan fleksibel. Pertama client memberikan materi iklannya yang bersifat mentah (belum diolah) kepada pihak media, kemudian konten iklan tersebut diolah menjadi bentuk video dengan format file mov. Setelah jadi video yang telah diolah, diperlihatkan kepada klien untuk persetujuan sebelum tampil di videotron, setelah video disetujui klien, pihak media akan segera memasukan video tersebut ke videotron menggunakan computer server. Sedangkan untuk klien 
yang sudah memiliki konten iklan dalam bentuk video tentunya akan lebih mudah, karena tinggal menyesuaikan dengan ukuran resolusi videotron tersebut, kemudian video siap untuk ditampikan.

Sedangkan untuk mengukur efektivitas media videotron ini, pihak media AD bekerjasama dengan pihak ketiga dalam melakukan riset untuk mendapatkan informasi terkait efektivitas medianya. Sejauh ini media videotron masih menjadi salah satu media baru yang cukup diminati oleh seluruh masyarakat, terbukti dari beberapa perusahaan-perusahaan swasta, BUMN dan pemrerintah yang beriklan pada media ini selain karena tampilannya yang menarik, videotron juga dikenal sebagai media luar ruang informatif yang exclusive karena harganya yang terbilang mahal. Akan tetapi sebenarnya untuk memasang iklan di videotron juga cukup mudah, dengan bermodalkan kurang lebih Rp.10.000.- /tayang, iklan video kita sudah bisa tampil di media luar ruang raksasa ini.

Namun agar efektif, pihak media AD membatasi durasi iklan pada setiap tayangan di media ini. Durasi terpanjang iklan pada media videotron maksimal menggunakan durasi 30 detik, sedangkan untuk durasi terpendek minimal 15 detik. Hal ini diperhitungkan bahwa pengendara berhenti atau berada di dekat videotron paling lama 30 detik, kemudian melanjutkan perjalanannya. Durasi iklan ini juga dibuat singkat agar memastikan ketersampaian keseluruhan pesan kepada pengguna jalan. Namun dari pihak media AD sendiri menyarankan kepada seluruh kliennya, untuk membuat iklan video dengan durasi 15 detik agar efektif sehingga pesan yang disampaikan tidak terlalu Panjang dan dapat terlihat oleh pengendara hingga selesai.

Selain kelebihan yang disajikan oleh media baru ini, menurut pak Gianto efek negative dari teknologi tentunya pasti akan ada. Media luar ruang videotron ini memiliki implikasi negative terhadap gangguan bahayanya tindakan peretasan oleh orang-orang yang tidak bertanggung jawab. Apabila hal ini terjadi oknum tersebut bisa menguasai videotron dan bisa menampilkan hal - hal yang sifatnya tidak pantas untuk ditampilkan, sehingga bisa merusak citra dari perusahaan. Seperti contoh kasus peretasan videotron yang terjadi di kota Surabaya kemarin, dimana pelaku memasukkan video porno dan menampilkannya ke dalam videotron. Tentunya hal inilah yang akan menjadi ancaman bagi pemilik maupun pengelola videotron.

Hal yang sama juga penulis dapatkan saat mewancarai beberapa informan terkait efektivitas videotron sebagai media penyampai pesan iklan kepada masyarakat. disampaikan bahwa videotron efektif dalam menyampaikan pesan iklan karena materi iklan dikemas dengan sedemikian rupa sehingga menjadi sebuah video atau tayangan yang bergerak sehingga memunculkan daya tarik sendiri untuk dilihat atau disaksikan. Media ini cukup berbeda dengan media luar ruang lainya salah satu dari perbedaan tersebut karena media ini berbasis digital sehingga membuat media ini telihat dinamis dan mempunyai daya tarik sendiri dibandingkan media luar ruang lainya yang bersifat statis. Hal inilah yang membuat media ini terlihat eksklusif dari media lainnya.

Salah satu kelebihan dari media videotron ini adalah karena mudahnya terbaca oleh pengguna jalan disbebakan karena letaknya yang berada di depan lampu rambu lalu lintas (lampu merah), sehingga berada di waktu yang tepat untuk menyajikan iklan video kepada seluruh pengguna jalan yang sedang berhenti karena adanya lampu merah. Pada saat ini focus pengendara tidak lagi berada pada pengendara lain yang ada di depannya, melainkan bisa dengan leluasa melihat iklan tayangan videotron ini. Selain itu media ini juga terlihat sangat menarik 
pada malam hari karena dilengkapi dengan pencahayaan yang cukup terang, memudahkan kita untuk melihat atau membaca pesan iklan tersebut. Bahkan tak jarang mata kita seakan-akan tepancing untuk memandang kea arah videotron tersebut karena cahayanya yang begitu terang.

Selain itu media ini memudahkan bagi para pengendara untuk mendapatkan informasi walaupun berada di jalan raya. Berbeda dengan pendapat umum yang mengatakan berada di jalan adalah kegiatan tidak produktif yang cukup banyak menghabiskan waktu. Karena dengan adanya videotron beragam informasi terdapat dalam media videotron ini baik iklan komersil maupun iklan layanan masyarakat yang ditampilkan secara bergantian. Sehingga semakin banyak pesan yang dapat dilihat atau diserap bagi para pengguna jalan raya. Cukup kontradiksi dengan media luar ruang lainya yang hanya bisa menyajikan satu jenis iklan saja, media ini dapat menampilkan hingga 15 jenis iklan dalam satu media. Hal inilah yang diungkapkan oleh beberapa informan saat penulis melakukan wawancara langsung di lokasi sekitaran videotron jalan andi pangeran pettarani.

Adapun implikasi dari media luar ruang videotron menurut informan yang dalam hal ini adalah masyarakat pengguna jalan mengatakan. Dirinya merasa terganggu ketika melihat media itu dalam keadaan berkendara karena menurut informan bisa mengganggu konsentrasi dalam berkendara. Selain itu informan juga memberikan contoh seorang pengendara yang menyaksikan iklan pada videotron dalam keadaan berkendara pasti akan melambatkan kendaraannya dan hal inipun yang akan menghalangi atau mengganggu pengendara lainnya dalam melaju di tengah jalan. Kejadian seperti ini biasa terjadi dan sering kita saksikan di sekitaran videotron yang letaknya tidak dekat dengan tempat pemberhentian kendaraan Selain itu juga menurut informan lainnya yang menjadi dampak negative videotron terhadap pengguna jalan adalah silaunya cahaya lampu pada videotron di malam hari. Hal ini dikemukan oleh beberapa informan yang sering melewati videotron tersebut pada malam hari.

Kemudian bagaimana kaitan videotron dengan teori ini ?. Menurut hemat saya Uses and Gratification Theory adalah Teori Penggunaan dan Pemenuhan Kebutuhan. Theory Uses and Gratification adalah salah satu teori komunikasi massa di mana titik berat penelitian dilakukan pada khalayak sebagai penentu pemilihan pesan dan media. Uses and Gratification Theory yang merupakan salah satu dari teori komunikasi massa melihat khalayak dari proses komunikasi massa sebagai individu yang aktif, selektif dan memiliki tujuan tertentu terkait dengan terpaan media kepadanya.

Hubungan videotron dengan teori ini adalah pengguna dalam hal ini masyarakat aktif dan dan berhak menentukan media apa, melalui apa dan bentuk informasi apa yang ingin didapatkan. Ada berbagai macam jenis media luar ruang yang digunakan untuk menyebarkan pesan, baik itu pesan iklan maupun pesan iklan layanan masyarakat diantaranya billboard, baliho, poster, brosur, videotron dan lain-lain. Namun masyarakat berhak memilih jenis media apa yang akan digunakan untuk menerima pesan iklan tersebut. Khususnya di era digital yang didominasi oleh kaum milenial ini kebanyakan menggunakan alat teknologi informasi dan komunikasi untuk melakukan aktivitasnya, seperti menulis melalui note smartphone, membaca koran melalui enewspaper, mengirim pesan melalui email, mengirim uang melalui fintech dan lain-lain.

Begitupun dengan hadirnya videotron menjadi media alternative baru bagi media luar ruang lainya yang dahulu marak digunakan. Dengan hadirnya videotron biaya operasional iklan 
akan sedikit menurun, disebabkan tidak adanya biaya tambahan untuk pencetakan dan biaya pembuatan konstruksi sebagai bahan pendukung atau dudukan media luar ruang lainnya. cukup dengan membayar biaya sewa kepada pemilik videotron yang sama halnya kita membayar pajak jika menggunakan media luar ruang lainnya. Bahkan hanya dengan menggunakan sebuah konten desain berupa foto maupun video, iklan tersebut sudah bisa ditampilakan dengan mudah pada media videotron. Menariknya gambar atau video yang ditampilkanpun sangat dinamis dan didukung dengan visual-visual yang kreatif.

Hal inilah yang membuat videotron menjadi efektif baik dari segi pengiklan juga bagi pengguna. Hal itulah yang menjadi daya tarik bagi pengiklan karena media teknologi dalam hal promosi di luar ruang merupakan sesuatu yang baru dan inovatif. Oleh karena media ini dapat menampilkan beberapa jenis iklan gambar maupun video dalam satu media. Sehingga tidak dipungkiri masyarakat dalam melihat videotron, dapat menyaksikan satu atau dua jenis informasi iklan sekaligus secara bergantian. Dan pada akhirnya dari segi lingkunganpun dapat meminimalisir iklan-iklan berbasis cetak pada media luar ruang yang dapat menimbulkan sampah-sampah visual.

Lantas siapa sebenarnya target sasaran bagi media videotron ? jawabanya adalah seluruh masyarakat yang menggunakan jalan raya dan yang berada di sekitar media tersebut. Namun tentunya videotron memiliki target pasar khususnya bagi orang-orang yang melek akan teknologi, dengan segala aktivitas yang bersentuhan langsung dengan media-media teknologi informasi dan komunikasi. Media videotron kini menjadi media alternative bagi masyarakat, yang ingin memasang iklan dengan menggunakan media teknologi. Hal ini pula lah yang menjadikan media luar ruang ini exclusive dibanding media luar ruang lainnya.

\section{DAFTAR PUSTAKA}

Arikunto, Suharsimi. 2005. Manajemen Penelitian. Jakarta: Rineka Cipta.

Cangara, Hafid. 2006. Pengantar Ilmu Komunikasi. PT. Raja Grafindo.

Effendy, Onong Uchjana 2003. Ilmu, Teori dan Filsafat Komunikasi. Bandung: PT Citra Aditya.

Effendy, Onong Uchjana. 2003. Ilmu Komunikasi: Teori dan Praktek. Bandung: PT Remaja Rosdakarya

Jenkins, Henry. 2002. Convergence Culture: Where Old and New media Collide. New York: New York university press.

Kasali, Rhenald. 1992. Manajemen Periklanan: Konsep dan Aplikasinya di Indonesia. Jakarta: PT.Pustaka Utama Grafiti

Kotler, Philip. 2005. Marketing Management: Analisis, Planning, Implemrntation, and Control. New Jersey: A Paramount Communication Company

Kotler, Philip. 2014. Marketing Management: Analisis, Planning, Implemrntation, and Control. New Jersey: A Paramount Communication Company

Kriyantono, Rachmat. 2008. Teknik Praktis Riset Komunikasi: Disertai Contoh Praktis Riset Media, Public Relation, Advertising, Komunikasi Organisasi, Komunikasi Pemasaran. Jakarta: Kencana Prenada Media Group

Miles, Matthew B., Huberman, \& A. Michael. 1984. Qualitative Data Analysis: A Source of New Methods. London: Sage Publications. 
Ridwan, Mochammad. 2012. Pengaruh Iklan PT. Djarum Melalui Videotron Terhadap Brand Awareness (survey pada pengguna jalan Abu Bakar Ali Yogyakarta). Skripsi. FISIP UIN Sunan Kalijaga Yogyakarta.

Suyanto, M. 2006. Strategi Perancangan Iklan-Iklan Outdoor kelas Dunia. Yogyakarta: Andi offset.

Tjiptono, Fandy \& Chandra, Gregorius. 2008. Pemasaran Strategik. Yogyakarta: Andi offset.

http://mirzublogfree.blogspot.com/2011/04/media-periklanan-alternatif.html, diakses pada hari Kamis 16 Februari 2018.

Thurlow, Crispin. Computer Mediated Communication, (London: Sage Publication, 2009) John P.Pavlik. New media Technology: Cultural and commercial Perspektive. (Boston: Allyn and Boston)

Widyatama, Rendra. 2005. Pengantar Periklanan. Jakarta: Buana Pustaka Indonesia. 